\title{
Characteristics of Kawasaki Disease Patients during the COVID-19 Pandemic in Japan: A Single-Center, Observational Study
}

\author{
Shoichi Shimizu (D, Mamoru Ayusawa *, Hidetoshi Go, Kimitaka Nakazaki, Hidemasa Namiki, Yuki Kasuga, \\ Koji Nishimura, Koji Kanezawa, Tamaki Morohashi and Ichiro Morioka (D)
}

check for updates

Citation: Shimizu, S.; Ayusawa, M.; Go, H.; Nakazaki, K.; Namiki, H.; Kasuga, Y.; Nishimura, K.; Kanezawa, K.; Morohashi, T.; Morioka, I. Characteristics of Kawasaki Disease Patients during the COVID-19 Pandemic in Japan: A Single-Center, Observational Study. Children 2021, 8 , 913. https://doi.org/10.3390/ children 8100913

Academic Editor: Ho-Chang Kuo

Received: 21 September 2021

Accepted: 12 October 2021

Published: 13 October 2021

Publisher's Note: MDPI stays neutral with regard to jurisdictional claims in published maps and institutional affiliations.

Copyright: (c) 2021 by the authors. Licensee MDPI, Basel, Switzerland. This article is an open access article distributed under the terms and conditions of the Creative Commons Attribution (CC BY) license (https:// creativecommons.org/licenses/by/ $4.0 /)$.
Department of Pediatrics and Child Health, Nihon University School of Medicine, Tokyo 173-8610, Japan; shimizu.shoichi@nihon-u.ac.jp (S.S.); go.hidetoshi@nihon-u.ac.jp (H.G.); nakazaki.kimitaka@nihon-u.ac.jp (K.N.); hidemasa.namiki@nihon-u.ac.jp (H.N.); kasuga.yuki@nihon-u.ac.jp (Y.K.); nishimura.koji@nihon-u.ac.jp (K.N.); kanezawa.koji33@nihon-u.ac.jp (K.K.); morohashi.tamaki@nihon-u.ac.jp (T.M.); morioka.ichiro@nihon-u.ac.jp (I.M.)

* Correspondence: ayusawa.mamoru@nihon-u.ac.jp; Tel.: +81-339-728-111 (ext. 2442)

Abstract: Background: Under the Coronavirus disease 2019 (COVID-19) pandemic, manifestations in children with Kawasaki disease (KD) are different between the Western and the Eastern countries. Particularly, there has not been a report comparing a series of KD in Japan, where KD was originally discovered and has a large number of registered cases. Methods: We compared patients with KD under the period of the COVID-19 pandemic in Japan with the report from Italy during its reported period by a retrospective, cohort, observational study in a Japanese single center. Results: Thirty-two patients with typical KD were treated during the study period, while the Italian study reported 10 patients with the signs of KD. Concerning the proof of severe acute respiratory syndrome coronavirus type 2 (SARS-CoV-2) infection, none $(0 \%)$ of our KD cases showed a positive result and one and no patients developed the macrophage activation syndrome (MAS) and Kawasaki disease shock syndrome (KDSS), respectively; however, eight (80\%) patients in the Italian series were confirmed with SARS-CoV-2 infection. MAS and KDSS developed in six and five patients, respectively. Conclusions: Cases reported as COVID-19 pandemic-related KD in Italy showed significantly different clinical characteristics from the typical KD symptoms known in Japan. Although they show KD-like manifestations, we cannot conclude that SARS-CoV-2 has the same etiology of our 'classic' KD at the present stage.

Keywords: coronavirus disease 2019; Kawasaki disease; Japan; severe acute respiratory syndrome coronavirus type 2; pandemic; vasculitis

\section{Introduction}

The new coronavirus (severe acute respiratory syndrome coronavirus type 2, SARSCoV-2) outbreak, which broke out in Wuhan, China, in December 2019, has spread to many countries around the world and continues to rage. Infections caused by this new virus can range from asymptomatic to minor symptoms of the common cold and, in some patients, later progressing to respiratory failure and multiple organ damage due to severe pulmonary lesions [1]. The disease caused by this virus has been named Coronavirus disease 2019 (COVID-19) by the World Health Organization [2]. While severe cases and deaths are a serious problem in adults, the number of children developing the disease is low from the pandemic onset, and, even if infected, children have few symptoms [3]. In Japan, no deaths in children under 19 years of age have been reported so far.

Incidentally, Kawasaki disease (KD) is relatively common among Japanese children, with 17,364 cases in 2018 [4]. KD was originally discovered in Japan, and Japanese nationwide surveillance officially reports the prevalence in 2018 was as high as 359 patients $/ 100,000$ children aged 
0-4 years [4]. Differences in prevalence have been observed between races, and the disease has been considered relatively rare in the Western countries [5]. However, between March and April of 2020, eight children with severe inflammatory shock were seen during the SARS-CoV-2 epidemic, first reported in the United Kingdom [6]. In the outbreak of SARSCoV-2 infection in Bergamo province, Italy [7], which we compared in the present study, $\mathrm{KD}$ was found in a series of 10 cases with symptoms seen in succession. In addition, from the United States and France, there has been a rapid increase in the number of critically ill patients requiring intensive care among young patients confirmed to have been infected with each outbreak. They have called those cases multisystem inflammatory syndrome in children (MIS-C) [8-11] or have named it pediatric inflammatory multisystem syndrome (PIMS) in several reports. [12] A French multicenter study reported on the disease, calling it 'Kawa-COVID-19 [9]'. All reports mentioned above were published in early July. They emphasized that KD-like manifestations occurred in 30-70\% of cases. However, because no cases of MIS-C or PIMS were observed during the early COVID-19 pandemic in Japan, we considered that the characteristics of MIS-C or PIMS would be different from those of original KD, which often develops in Japan.

In the present study, therefore, we evaluated the association between original KD cases at our hospital during the COVID-19 pandemic and SARS-CoV-2 infection using realtime reverse transcriptase-polymerase chain reaction (PCR) or loop-mediated isothermal amplification (LAMP) assay and/or qualitative tests for SARS-CoV-2 immunoglobulin G (IgG) and immunoglobulin $\mathrm{M}(\mathrm{IgM})$ by immunochromatography. Then we compared the characteristics of KD patients treated at our hospital between 1 April and 30 June with those during the same period in 2019 in our hospital, and those during the COVID-19 pandemic in Italy.

\section{Materials and Methods}

A retrospective, cohort, observational study was performed, and the clinical characteristics were compared for children with KD treated at our hospital from April to June 2020 and April to June 2019. Then we compared the characteristics of KD treated at our hospital from 1April 2020 to 31 August 2021 with the Italian series reported by Verdoni and colleagues [7].

Our pediatrics department is housed within a tertiary care institution, encountering around 1000-1500 inpatients per year, in Tokyo, Japan. The number of inpatients with KD was 69.0/year from 2012-2016. First, we compared the age, sex, percentage of insufficiency type, Kobayashi score value that predicts severity for KD, including age of onset, days of illness, percent of neutrophils, platelet count, and serum levels of aspartate aminotransferase, sodium, and C-reactive protein [13], and presence of coronary artery lesions between patients with KD treated at our hospital between April and June 2020 with those treated during the same time in 2019. Next, we evaluated the association between SARS-CoV-2 infection and KD patients at our hospital between April and June 2020, using PCR or LAMP assays for SARS-CoV-2 (Eiken Chemical Co., Ltd., Tokyo, Japan) and qualitative antibody tests for IgG and IgM (immunochromatography: INNOVITA ${ }^{\circledR}$ 2019-nCoV Ab Test; Tangshan, China). These antibody tests were not able to be examined after July 2020 because of financial resources. Clinical characteristics, age of onset, Kobayashi score level, number of diagnosed cases of incomplete KD, blood test findings, concomitant symptoms, and proportion of patients presenting with KD shock syndrome (KDSS) and macrophage activation syndrome (MAS) were compared with the data of patients with KD during the COVID-19 epidemic in Italy. For the diagnostic criteria of KD, we used the AHA, 2017, for Italian cases [14]. For the study of our cases, we followed the revised fifth edition of the "Diagnostic Guidelines of Kawasaki disease" 2002 [15] to unify the condition of subjects in Japan. Coronary artery lesion is defined when the z-score of its inner diameter is +2.5 or more [16]. MAS is defined according to the classification in systemic juvenile idiopathic arthritis using a set of the Ferritin more than $684 \mathrm{ng} / \mathrm{mL}$, and any two of platelet count $\leq 181 \times 109 / \mathrm{L}$, aspartate aminotransferase $>48 \mathrm{U} / \mathrm{L}$, triglycerides $>156 \mathrm{mg} / \mathrm{dL}$, 
and fibrinogen $\leq 360 \mathrm{mg} / \mathrm{dL}$, which were also used for the case series in Italy [17]. KDSS is defined as KD patient with a sustained decrease in systolic blood pressure from baseline for age of $20 \%$ or more or with poor perfusion recognized clinically [18].

For the statistical test, Fisher's exact test was used for the comparison of categorical variables, and the Mann-Whitney U test was used for comparison of continuous variables. We used JMP pro 14 (@ SAS Institute Inc., Minato-ku, Tokyo, Japan) as a software for statistical program. This study was conducted with the approval of the Ethics Committee (Nihon University Research Committee \#RK-200714-4, approved on 14 July 2020).

\section{Results}

The profiles of KD patients in our hospital from April to June 2020 were compared to those from the same period in 2019. No significant difference was found in the number of patients, age of onset, sex, percentage of incomplete type, and Kobayashi score value. One case of coronary artery lesions in 2019 and two cases in 2020 were temporary and regressed to normal range within a month.

Then we listed and reviewed the characteristics of KD patients treated at our hospital between 1 April 2020 and 31 August 2021. All 32 patients were negative for PCR or LAMP for SARS-CoV-2 ( $\%$, Table 1$)$. All 18 patients who underwent qualitative testing for IgG and IgM were negative for both IgG and IgM (Table 1). One patient showed the symptoms for MAS. None of the patients developed KDSS. Only one patient presented with diarrhea as an accompanying symptom. One patient had convulsions and disturbance of consciousness as an accompanying symptom, but showed improvement.

Table 1. Summary of the results of the tests for severe acute respiratory syndrome coronavirus type 2 and treatments in our hospital and in Italy.

\begin{tabular}{cccc}
\hline & Ours & Italy [7] & $p$-Value \\
\hline Study period & April 2020-August 2021 & March-April 2020 & \\
Number of patients & 32 & 10 & $<0.05$ \\
Nasal swab PCR for SARS-CoV-2 & $0 / 32(0 \%)$ & $2 / 10(20 \%)$ & $<0.01$ \\
Serology test for SARS-CoV-2 IgG & $0 / 18(0 \%)$ & $5 / 10(50 \%)$ & $<0.05$ \\
Serology test for SARS-CoV-2 IgM & $0 / 18(0 \%)$ & $3 / 10(30 \%)$ & $</ 10(80 \%)$ \\
Use of adjunctive steroids & $10 / 32(31 \%)$ & $2 / 10(20 \%)$ & $<0.05$ \\
Use of inotropes & $0 / 32(0 \%)$ & & $<$ \\
\hline
\end{tabular}

p-value was analyzed by Fisher's exact test. PCR: real-time reverse transcriptase-polymerase chain reaction; SARS

CoV-2: severe acute respiratory syndrome coronavirus type 2; IgG: immunoglobulin G; IgM: immunoglobulin M.

The characteristics of KD patients during the COVID-19 epidemic in Italy are shown in Tables 1 and 2 [7]. Because two patients were not detected either in PCR or antibodies' testing, eight ( $80 \%$ ) patients were confirmed SARS-CoV-2 infection. A PCR for SARS-CoV-2 from nasal swab was positive in two of the 10 cases. An antibody test was positive for IgG only in five cases, and both IgG and IgM were positive in three cases (Table 1). Diarrhea was seen as an accompanying symptom in six cases. MAS and KDSS developed in six and five patients, respectively.

Table 2. Comparisons of the clinical data of Kawasaki disease patients in our hospital and in Italy.

\begin{tabular}{cccc}
\hline & Ours & Italy [7] & $p$-Value \\
\hline Period of Investigation & April 2020-August 2021 & March-April 2020 & \\
Number of Patients & 32 & 10 & \\
Age (years) & $1.8 \pm 1.1$ & $7.5 \pm 3.5$ & $<0.01$ \\
Male & $21(66 \%)$ & $7(70 \%)$ & 0.8 \\
Incomplete KD & $1 / 32(3 \%)$ & $5 / 10(50 \%)$ & $<0.01$ \\
Kobayashi score & $3.0 \pm 2.1$ & $5.1 \pm 1.5$ & $<0.01$ \\
Kobayashi score $>5$ & $8 / 32(25 \%)$ & $7 / 10(70 \%)$ & $<0.01$ \\
CRP(mg/dL) & $7.3 \pm 5.0$ & $25 \pm 15.3$ & $<0.01$ \\
Neutrophils $(\%)$ & $62.2 \pm 19.3$ & $84.5 \pm 5.7$ & $<0.01$ \\
Platelets $\left(\times 10^{9} / \mathrm{L}\right)$ & $345 \pm 122$ & $130 \pm 32$ & $<0.01$ \\
\hline
\end{tabular}


Table 2. Cont.

\begin{tabular}{cccc}
\hline & Ours & Italy [7] & $p$-Value \\
\hline Sodium $(\mathrm{mEq} / \mathrm{L})$ & $135.7 \pm 3.5$ & $130.8 \pm 3.9$ & $<0.01$ \\
AST (U/L) & $76.9 \pm 101$ & $87 \pm 70$ & 0.76 \\
Fibrinogen $(\mathrm{mg} / \mathrm{dL})$ & $526 \pm 128$ & $1176 \pm 1032$ & 0.14 \\
MAS & $1 / 32(3 \%)$ & $5 / 10(50 \%)$ & $<0.01$ \\
KDSS & $0 / 32(0 \%)$ & $5 / 10(50 \%)$ & $<0.01$ \\
Coronary artery dilation & $2 / 32(6 \%)$ & $6 / 10(60 \%)$ & $<0.01$ \\
\hline
\end{tabular}

p-value was analyzed by Fisher's exact test or Mann-Whitney's U test. KD: Kawasaki diseases, CRP: C-reactive protein, AST: aspartate aminotransferase, MAS: macrophage activation syndrome, KDSS: Kawasaki disease shock syndrome.

Table 1 shows a summary of the results regarding the PCR and antibody tests for SARS-CoV-2 and treatments in our hospital and in Italy [7]. While 31\% of the patients at our hospital required steroid treatment, $80 \%$ of the Italian children required adjunctive steroids, and 20\% required inotropes. All items concerning SARS-CoV2 infection, steroid, and inotrope requirement were significantly different.

Table 2 shows comparisons of the clinical data of KD patients in our hospital and in Italy [7]. The age, high ratio of incomplete KD, Kobayashi score value and ratio of its high risk ( $\geq 5$ points), CRP value, high ratio of neutrophils, low platelet count, low serum sodium, high ratio of MAS or KDSS, and high proportion of coronary artery dilation were significantly worse between the Italian group and our cohort. Among the parameters including Kobayashi score, all parameters, except for serum aspartate aminotransferase level in Italian cases, were significantly worse than those in ours. In the Italian group, the number of patients with incomplete KD was also high and many cases of MAS and KDSS were found.

\section{Discussion}

In 2020, the unexpected SARS-CoV-2 pandemic continued through summer and into the early autumn. We compared the clinical characteristics of KD patients during the same 3-month period with the previous year (2019) because the number of KD patients has a seasonal variation [4]. We found no significant difference of clinical characteristics in KD patients during the SARS-CoV-2 epidemic in 2020 compared to that in 2019, such as the age of onset and the severity of the disease using the Kobayashi score.

In Japan, a questionnaire survey polling major centers belonging to the Japanese Society of Kawasaki Disease showed no change in the morbidity and severity of KD. No case associated with COVID-19 infection was observed [18]. However, unfortunately, this survey did not investigate the detailed characteristics of the registered cases. As of this writing, one case, who developed KD after SARS-CoV-2 infection in Japan, was reported, but a causal relationship between the two diseases remained unknown [19]. Thereafter, despite the accumulation of pediatric cases with SARS-CoV-2 infections, no KD patients associated with COVID-19 appeared. We, therefore, conducted this current study to compare with representative cases associated with COVID-19 from Italy [7]. Compared between cases from Italy and our Japanese cases, the two cohorts were quite different in age of onset, Kobayashi score, and vasculitis markers, as well as a number of incomplete cases and accompanying symptoms, such as abdominal symptoms and neurological symptoms. In addition, comparisons with the reports from representative Western countries are summarized in Table 3 [6-12]. The onset age was high, including teenagers, and the race was predominantly African and Hispanic (Asian ethnicity in less than 5\%). In addition, symptoms other than principal signs of typical KD, such as gastrointestinal and arthritic symptoms, hypotension, myocarditis, and MAS or KDSS symptoms, appeared in nearly half of the patients [6-12]. Intravenous immunoglobulin was used in almost all cases, but many were refractory [6-12]. 
Table 3. The onset age and race of Kawasaki disease induced by severe acute respiratory syndrome coronavirus type 2 infections in Western countries.

\begin{tabular}{|c|c|c|c|c|c|}
\hline Author \& Area & Period & $\begin{array}{c}\text { Number } \\
\text { of KD-Like Pts. }\end{array}$ & Age & $\begin{array}{l}\text { Sex } \\
\text { (M:F) }\end{array}$ & Race \\
\hline Verdoni et al. [7] Italy & 17 March to 14 April & 10 & avg. 7.5 & $7: 3$ & White $8 / 10$ \\
\hline Riphagen et al. [6] UK & 10 days in mid-April & 8 & $4-14$ & $5: 3$ & $\begin{array}{l}\text { A-C 6, M-E } 1 \\
\text { Asian } 1\end{array}$ \\
\hline Whittaker et al. [12] UK & 23 March to 16 May & 13 & median $=9$ & $10: 3$ & $\begin{array}{c}\text { Black 8, White } 4 \\
\text { M-E } 1\end{array}$ \\
\hline Toubiana et al. [8] France & 27 April to 11 May & 21 & avg. 7.9 & $9: 12$ & $\begin{array}{c}\text { Black } 12(57 \%) \text {, Asian } \\
3(14 \%)\end{array}$ \\
\hline Pouletty et al. [9] France & $\begin{array}{l}6 \text { weeks } \\
\text { from April }\end{array}$ & 16 & median 10 & $8: 8$ & $\begin{array}{c}\text { A-C } 10(62 \%), \\
\text { M-E } 2(12 \%), \\
\text { European } 4(25 \%) \\
\text { Asian } 0\end{array}$ \\
\hline Feldstein et al. [10] USA & 15 March to 20 May & 74 & $\begin{array}{l}\text { cKD Av. } 5.7 \\
\text { iKD Av. } 8.4\end{array}$ & - & $\begin{array}{c}\text { not written } \\
\text { for KD patients }\end{array}$ \\
\hline Dufort et al. [11] USA & before 10 May & 36 & $\begin{array}{l}0-5 \text { y: } 15 / 36 \\
6-12 \text { y: } 18 / 36 \\
13-20 \text { y: } 3 / 36\end{array}$ & - & $\begin{array}{c}\text { White } 37 \% \text {, Black } \\
40 \% \text {, Asian } 5 \%, \\
\text { American native } 18 \%\end{array}$ \\
\hline
\end{tabular}

Av: average, KD: Kawasaki disease, y: years, cKD: complete KD, iKD: incomplete KD, A-C: Afro-Caribbean, M-E: Middle Eastern.

In 2005, Esper et al. [20] conducted a study to determine the cause in eight out of 11 children with KD, who developed between November and April. They detected 'New Heaven Corona Virus (HCoV-NH)' by PCR in respiratory secretions from these KD patients, although only one was detected in 22 control cases. Thus, this virus was considered as one of the potential causes of KD. However, 47 among 48 patients in the United States and the Netherlands [21] and all 53 cases in Taiwan [22] during the same year had a negative result for $\mathrm{HCoV}-\mathrm{NH}$, resulting that $\mathrm{HCoV}-\mathrm{NH}$ was not a cause of $\mathrm{KD}$. Although $\mathrm{HCoV}-\mathrm{NH}$ is an a-CoV genus by genetic classification, SARS-CoV-2 is a b-CoV genus, similar to the SARS virus from the greater horseshoe bat in the 2002 pandemic and the Middle East respiratory syndrome virus from the dromedary in the 2012 pandemic. The relationship between SARS-CoV-2 and KD would receive renewed attention in this era of the SARS-CoV-2 pandemic.

SARS-CoV-2 adheres to the angiotensin II-converting enzyme receptor upon invasion of infected target cells [23]. Then, increased inflammatory response, reactive oxygen release, vasoconstriction, and thrombus formation induce vasculitis and thrombosis. This response induces an activation of macrophages, which leads to neutrophil release and cytokines [24]. The markers of vasculitis, such as CRP, interleukin 6, D-dimer, and natriuretic peptide, are elevated in serum. As the results, the mucosal symptoms will appear like KD. At the same time, multisystemic vasculitis and subsequent tissue damage may develop a more severe form than typical KD [25]. The target organs are mostly pulmonary capillaries in adults, but in children, the gastrointestinal and cardiovascular systems seem to be more prevalent, leading to MIS-C or PIMS showing the symptoms similar to KD.

In Japan, a few cases of MIS-C or PIMS were reported after December 2020 [26-29]. We reviewed those reports according to the items in Table 1, and added Table 2, and their summary is added on Table 4. Comparing with Italy's series and ours, Japanese MIS-C or PIMS cases are very close to Italy's series rather than our KD series. Therefore, MIS-C or PIMS will possibly increase also in Japan after many more patients are infected with SARS-CoV-2. The majority of COVID-19 cases in Japanese children show very mild symptoms, such as low-grade fever or mild cough, or are asymptomatic [30]. However, only a few patients have a possibility to develop signs of MIS-C or PIMS-TS after several weeks in Japan. 
Table 4. Comparison with Japanese reported cases of MIS-C or PIMS.

\begin{tabular}{|c|c|c|c|c|c|}
\hline & Mean & $\begin{array}{l}\text { Uchida } \\
\text { et al. [26] }\end{array}$ & $\begin{array}{c}\text { Baba } \\
\text { et al. [27] }\end{array}$ & $\begin{array}{l}\text { Fukuda } \\
\text { et al. [28] }\end{array}$ & $\begin{array}{l}\text { Takasago } \\
\text { et al. [29] }\end{array}$ \\
\hline Number of Patients & & 1 & 1 & 1 & 1 \\
\hline Age (years) & 11 & 16 & 10 & 9 & 9 \\
\hline Male & $3 / 4(75 \%)$ & M & $\mathrm{F}$ & M & M \\
\hline Incomplete KD & $1 / 4(25 \%)$ & $\mathrm{Y}(3 / 6)$ & $\mathrm{N}(6 / 6)$ & $N(6 / 6)$ & $\mathrm{N}(6 / 6)$ \\
\hline Kobayashi score & 5 & 6 & 4 & 5 & 5 \\
\hline Kobayashi score $>5$ & $3 / 4(75 \%)$ & $\mathrm{Y}$ & $\mathrm{N}$ & $\mathrm{Y}$ & $\mathrm{Y}$ \\
\hline $\mathrm{CRP}(\mathrm{mg} / \mathrm{dL})$ & 22.1 & 20.6 & 21.9 & 22.6 & 23.1 \\
\hline Neutrophils (\%) & $92 \%$ & $93 \%$ & $91 \%$ & $92 \%$ & $90 \%$ \\
\hline Platelets (x109 /L) & 169 & 130 & 72 & 315 & 158 \\
\hline Sodium (mEq/L) & 130 & 132 & 131 & 129 & 126 \\
\hline AST (U/L) & 47 & 40 & 41 & 45 & 62 \\
\hline Fibrinogen (mg/dL) & 665 & 606 & 605 & 758 & 691 \\
\hline MAS & 0 & $\mathrm{~N}$ & $\mathrm{~N}$ & $\mathrm{~N}$ & $\mathrm{~N}$ \\
\hline KDSS & $3 / 4(75 \%)$ & $\mathrm{Y}$ & $\mathrm{N}$ & $\mathrm{Y}$ & $\mathrm{Y}$ \\
\hline Coronary artery dilation & $1 / 4(25 \%)$ & $\mathrm{N}$ & $\mathrm{Z}=3.88(\mathrm{LMT})$ & $\mathrm{N}$ & $\mathrm{N}$ \\
\hline $\begin{array}{l}\text { duration after contact with } \\
\text { SARS-CoV-2 }\end{array}$ & 28 & 23 & unknown & 30 & 31 \\
\hline
\end{tabular}

Until October 2021, a few unpublished cases of MIS-C or PIMS were informed in addition to four published cases [26-29]. However, MIS-C or PIMS is still very rare, counting approximately 10 in Japan. As of this writing, the number of COVID-19 and MIS-C patients under 18 years old in the United States is approximately 5,900,000 and 5200, respectively [31,32], while those of Japan are approximately 260,000 [30] and around 10, respectively. We estimate that the morbidity of MIS-C or PIMS in Japan is markedly lower than that in the United States. The reason for such racial difference is expected to be a future study.

Considering the above discussions, it seems that the Kawasaki-like symptoms associated with SARS-CoV-2 infection may represent a different picture from the typical KD that we have in a single center in Japan. However, as described below, it is clear that SARS-CoV-2 is a vasculitis-causing virus, and coronary artery involvement was observed in $6-24 \%$ of the reported cases [26]. The inflammation of the coronary arteries may spill over into other arteries, as in KD. It is necessary to be cautious if there is an outbreak of KD signs in children during the COVID-19 pandemic.

As a limitation, our study, including the associated reports, was conducted at a specific time when the number of patients was small. It is necessary to accumulate more KD cases during the COVID-19 pandemic to elucidate the pathogenesis of MIS-C or PIMS.

\section{Conclusions}

Cases of COVID-19 epidemic-related KD in Italy show significantly different characteristics from the typical KD symptoms known in Japan. Although they meet the criteria for $\mathrm{KD}$, we should consider them as a different type of vasculitis. 
Author Contributions: Conceptualization, M.A. and I.M.; Data curation, S.S., H.G., K.N. (Kimitaka Nakazaki) and K.N. (Koji Nishimura); Formal analysis, S.S., M.A., K.N. (Koji Nishimura) and K.K.; Investigation, S.S., K.N. (Kimitaka Nakazaki), H.N., Y.K., K.N. (Koji Nishimura), K.K. and T.M.; Methodology, T.M. and I.M.; Project administration, I.M.; Resources, H.G., K.N. (Kimitaka Nakazaki), H.N., Y.K., K.N. (Koji Nishimura) and K.K.; Supervision, T.M. and I.M.; Validation, I.M.; Writingoriginal draft, S.S. and M.A.; Writing - review and editing, M.A. and I.M. All authors have read and agreed to the published version of the manuscript.

Funding: This research was funded by the Grants-in-Aid for Challenging Exploratory Research of JSPS KAKENHI, grant number 19K21792 (to M.A.).

Institutional Review Board Statement: This study was conducted with the approval of the Ethics Committee (Nihon University Research Committee \# RK-200714-4; 200714-4; 14 July 2020).

Informed Consent Statement: Informed consent was obtained from all subjects involved in the study.

Data Availability Statement: The data that support the findings of this study are available from the corresponding author (M.A.), upon reasonable request.

Conflicts of Interest: The authors declare no conflict of interest.

\section{References}

1. Cao, Y.; Cai, K.; Xiong, L. Coronavirus disease 2019: A new severe acute respiratory syndrome from Wuhan in China. Acta Virol. 2020, 64, 245-250. [CrossRef]

2. World Health Organization. WHO Director-General's Remarks at the Media Briefing on 2019-nCoV on 11 February. 2020. Available online: https://www.who.int/dg/speeches/detail/who-director-general-s-remarks-at-the-media-briefing-on-2019 -ncov-on-11-february-2020 (accessed on 21 November 2020).

3. Ludvigsson, J.F. Systematic review of COVID-19 in children shows milder cases and a better prognosis than adults. Acta Paediatr. 2020, 109, 1088-1095. [CrossRef]

4. Results of the Japanese Nationwide Surveillance of Kawasaki Disease. (In Japanese). Available online: https:/ / www.jichi.ac.jp/ dph/wp-dph/wp-content/uploads/2020/09/e2e27b17833a88e36bf2008d23c9e385.pdf (accessed on 21 November 2020).

5. Uehara, R.; Belay, E.D. Epidemiology of Kawasaki disease in Asia, Europe, and the United States. J. Epidemiol. 2012, 22, 79-85. [CrossRef]

6. Riphagen, S.; Gomez, X.; Gonzalez-Martinez, C.; Wilkinson, N.; Theocharis, P. Hyperinflammatory Shock in Children During COVID-19 Pandemic. Lancet 2020, 395, 1607-1608. [CrossRef]

7. Verdoni, L.; Mazza, A.; Gervasoni, A.; Martelli, L.; Ruggeri, M.; Ciuffreda, M.; Bonanomi, E.; D’Antiga, L. An Outbreak of Severe Kawasaki-Like Disease at the Italian Epicentre of the SARS-CoV-2 Epidemic: An Observational Cohort Study. Lancet 2020, 395, 1771-1778. [CrossRef]

8. Toubiana, J.; Poirault, C.; Corsia, A.; Bajolle, F.; Fourgeaud, J.; Angoulvant, F.; Debray, A.; Basmaci, R.; Salvador, E.; Biscardi, S.; et al. Kawasaki-Like Multisystem Inflammatory Syndrome in Children during the covid-19 Pandemic in Paris, France: Prospective Observational Study. BMJ 2020, 369, m2094. [CrossRef] [PubMed]

9. Pouletty, M.; Borocco, C.; Ouldali, N.; Caseris, M.; Basmaci, R.; Lachaume, N.; Bensaid, P.; Pichard, S.; Kouider, H.; Morelle, G.; et al. Paediatric Multisystem Inflammatory Syndrome Temporally Associated with SARS-CoV-2 Mimicking Kawasaki Disease (Kawa-COVID-19): A Multicentre Cohort. Ann. Rheum. Dis. 2020, 79, 999-1006. [CrossRef] [PubMed]

10. Feldstein, L.R.; Rose, E.B.; Horwitz, S.M.; Collins, J.P.; Newhams, M.M.; Son, M.B.F.; Newburger, J.W.; Kleinman, L.C.; Heidemann, S.M.; Martin, A.A.; et al. Overcoming COVID-19 Investigators; CDC COVID-19 Response Team: Multisystem Inflammatory Syndrome in U.S. Children and Adolescents. N. Engl. J. Med. 2020, 383, 334-346. [CrossRef] [PubMed]

11. Dufort, E.M.; Koumans, E.H.; Chow, E.J.; Rosenthal, E.M.; Muse, A.; Rowlands, J.; Barranco, M.A.; Maxted, A.M.; Rosenberg, E.S.; Easton, D.; et al. New York State and Centers for Disease Control and Prevention Multisystem Inflammatory Syndrome in Children Investigation Team. Multisystem Inflammatory Syndrome in Children in New York State. N. Engl. J. Med. 2020, 383, 347-358. [CrossRef]

12. Whittaker, E.; Bamford, A.; Kenny, J.; Kaforou, M.; Jones, C.E.; Shah, P.; Ramnarayan, P.; Fraisse, A.; Miller, O.; Davies, P.; et al. Clinical Characteristics of 58 Children with a Pediatric Inflammatory Multisystem Syndrome Temporally Associated With SARS-CoV-2. JAMA 2020, 324, 259-269. [CrossRef] [PubMed]

13. Kobayashi, T.; Saji, T.; Otani, T.; Takeuchi, K.; Nakamura, T.; Arakawa, H.; Kato, T.; Hara, T.; Hamaoka, K.; Ogawa, S.; et al. RAISE study group investigators: Efficacy of immunoglobulin plus prednisolone for prevention of coronary artery abnormalities in severe Kawasaki disease (RAISE study): A randomised, open-label, blinded-endpoints trial. Lancet 2012, 379, 1613-1620. [CrossRef]

14. McCrindle, B.W.; Rowley, A.H.; Newburger, J.W.; Burns, J.C.; Bolger, A.F.; Gewitz, M.; Baker, A.L.; Jackson, M.A.; Takahashi, M.; Shah, P.B.; et al. Diagnosis, Treatment, and Long-Term Management of Kawasaki Disease: A Scientific Statement for Health Professionals From the American Heart Association. Circulation 2017, 135, e927-e999. [CrossRef] 
15. Ayusawa, M.; Sonobe, T.; Uemura, S.; Ogawa, S.; Nakamura, Y.; Kiyosawa, N.; Ishii, M.; Harada, K.; Kawasaki Disease Research Committee. Revision of Diagnostic Guidelines for Kawasaki Disease (The 5th Revised Edition). Pediatr. Int. 2005, 47, $232-234$. [CrossRef] [PubMed]

16. Kobayashi, T.; Fuse, S.; Sakamoto, N.; Mikami, M.; Ogawa, S.; Hamaoka, K.; Arakaki, Y.; Nakamura, T.; Nagasawa, H.; Kato, T.; et al. A New Z Score Curve of the Coronary Arterial Internal Diameter Using the Lambda-Mu-Sigma Method in a Pediatric Population. J. Am. Soc. Echocardiogr. 2016, 29, 794-801.e29. [CrossRef] [PubMed]

17. Ravelli, A.; Minoia, F.; Davì, S.; Horne, A.; Bovis, F.; Pistorio, A.; Aricò, M.; Avcin, T.; Behrens, E.M.; De Benedetti, F.; et al. 2016 Classification Criteria for Macrophage Activation Syndrome Complicating Systemic Juvenile Idiopathic Arthritis: A European League Against Rheumatism/American College of Rheumatology/Paediatric Rheumatology International Trials Organisation Collaborat. Arthritis Rheumatol. 2016, 68, 566-576. [CrossRef] [PubMed]

18. Kanegaye, J.T.; Wilder, M.S.; Molkara, D.; Frazer, J.R.; Pancheri, J.; Tremoulet, A.H.; Watson, V.E.; Best, B.M.; Burns, J.C. Recognition of a Kawasaki Disease Shock Syndrome. Pediatrics 2009, 123, e783-e789. [CrossRef]

19. Japanese Society of Kawasaki Disease. Concerning the Relationship between Kawasaki Disease and COVID-19. (In Japanese). Available online: http:/ / www.jskd.jp/pdf/20200506COVID-19andKD.pdf (accessed on 7 December 2020).

20. Esper, F.; Shapiro, E.D.; Weibel, C.; Ferguson, D.; Landry, M.L.; Kahn, J.S. Association Between a Novel Human Coronavirus and Kawasaki Disease. J. Infect. Dis. 2005, 191, 499-502. [CrossRef] [PubMed]

21. Shimizu, C.; Shike, H.; Baker, S.C.; Garcia, F.; Van Der Hoek, L.; Kuijpers, T.W.; Reed, S.L.; Rowley, A.H.; Shulman, S.T.; Talbot, H.K.B.; et al. Human coronavirus NL63 is not detected in the respiratory tracts of children with acute Kawasaki disease. J. Infect. Dis. 2005, 192, 1767-1771. [CrossRef]

22. Chang, L.-Y.; Chiang, B.-L.; Kao, C.-L.; Wu, M.-H.; Chen, P.; Berkhout, B.; Yang, H.; Huang, L.; Kawasaki Disease Research Group. Lack of Association between Infection with a Novel Human Coronavirus (HCoV), HCoV-NH, and Kawasaki Disease in Taiwan. J. Infect. Dis. 2006, 193, 283-286. [CrossRef]

23. Hatmal, M.M.; Alshaer, W.; Al-Hatamleh, M.A.I.; Hatmal, M.; Smadi, O.; Taha, M.O.; Oweida, A.J.; Boer, J.C.; Mohamud, R.; Plebanski, M. Comprehensive Structural and Molecular Comparison of Spike Proteins of SARS-CoV-2, SARS-CoV and MERS-CoV, and Their Interactions with ACE2. Cells 2020, 9, 2638. [CrossRef] [PubMed]

24. Liu, P.P.; Blet, A.; Smyth, D.; Li, H. The Science Underlying COVID-19: Implications for the Cardiovascular System. Circulation 2020, 142, 68-78. [CrossRef] [PubMed]

25. Sperotto, F.; Friedman, K.G.; Son, M.B.F.; VanderPluym, C.J.; Newburger, J.W.; Dionne, A. Cardiac manifestations in SARS-CoV-2associated multisystem inflammatory syndrome in children: A comprehensive review and proposed clinical approach. Eur. J. Pediatr. 2021, 180, 307-322. [CrossRef] [PubMed]

26. Uchida, M.; Kashima, Y.; Mochizuki, K.; Sakamoto, H.; Mori, K.; Ebisawa, S.; Takeshige, K.; Nitta, K.; Kuwahara, K.; Imamura, H. Multisystem Inflammatory Syndrome in Children-A New Syndrome Complicated With Acute Heart Failure Following Severe Acute Respiratory Syndrome Coronavirus 2 (SARS-CoV-2) Infection-. Circ. J. 2021, 85, 948-952. [CrossRef] [PubMed]

27. Baba, T.; Maruyama, T.; Katsuragi, S.; Maeda, K.; Kogaki, S. Multisystem inflammatory syndrome associated with SARS-CoV-2 in a Japanese girl. Pediatr. Int. 2021. [CrossRef]

28. Fukuda, S.; Kaneta, M.; Miyake, M.; Ohya, T.; Miyakawa, K.; Iwamoto, M.; Ito, S. A case of multisystem inflammatory syndrome in children in a Japanese boy: With discussion of cytokine profile. Mod. Rheumatol. Case Rep. 2021, 5, 442-447. [CrossRef]

29. Takasago, S.; Sakai, A.; Sugiyama, M.; Mizokami, M.; Hamada, H.; Ishizaka, Y.; Miyoshi-Akiyama, T.; Matsunaga, A.; Ueno, M.; Shichino, H.; et al. Case Report: Changes in Cytokine Kinetics during the Course of Disease in a Japanese Patient with Multisystem Inflammatory Syndrome in Children. Front. Pediatr. 2021, 9, 702318. [CrossRef] [PubMed]

30. Ministry of Health, Labour and Welfare. Confirmed Cases Detail Cumulative Weekly. Available online: https://covid19.mhlw.go. jp/ (accessed on 7 October 2021).

31. CDC. COVID Data Tracker. Available online: https://covid.cdc.gov/covid-data-tracker/\#mis-national-surveillance (accessed on 7 October 2021).

32. America Academy of Pediatrics. Children and COVID-19: State-Level Data Report. Available online: https://www.aap.org/en/ pages /2019-novel-coronavirus-covid-19-infections/children-and-covid-19-state-level-data-report/ (accessed on 7 October 2021). 